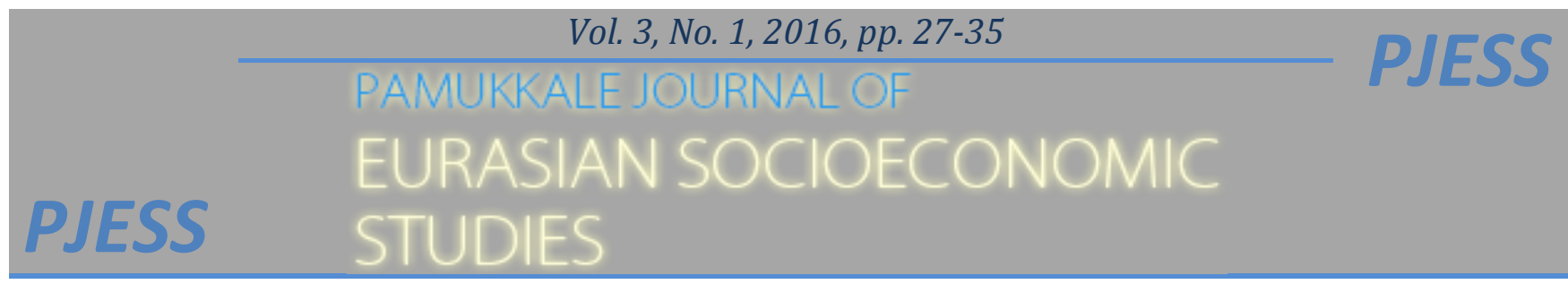

\title{
The Exchange Rate Overshooting in TURKEY
}

\author{
Türkiye'de döviz kuru hedef aşımı
}

\begin{abstract}
Sevcan GÜNEŞ ${ }^{1}$
Çağın KARUL ${ }^{2 a}$

${ }^{1}$ Pamukkale University, Faculty of Economics and Administrative Sciences, Denizli. sgunes@pau.edu.tr

2 Pamukkale University, Faculty of Economics and Administrative Sciences, Denizli. ckarul@pau.edu.tr a Corresponding author / Yazışılan yazar
\end{abstract}

Received/ Geliş Tarihi: 14.12.2015, Accepted/Kabul Tarihi: 27.07.2016

doi: 10.5505/pjess.2016.02986

\begin{abstract}
Introduced by Dornbusch in 1976, The Sticky Price Monetary Model applies to an exchange rate that is said to overshoot when its short-term response to changes in the money supply is greater than its long-term response, due to the domestic price level not adjusting instantaneously. In this study, we aim to investigate the overshooting hypothesis for Turkey. To this end, ARDL Model will be employed for the period from January 2000 to August 2014. The ARDL (5, 6, 1, 10, 5) ECM Model is estimated. Empirical results show that monetary shocks have caused an exchange rate overshooting in Turkey, even though the coefficients are statistically insignificant.
\end{abstract}

Keywords: Exchange rates, Sticky price monetary model, ARDL.

JEL codes: F31, C32

\section{Özet}

Dornbusch 1976 yılındaki "Yapışkan Fiyat Modeli Parasal Yaklaşım" olarak da adlandırılan çalışmasında; döviz kurunun parasal bir şoka karşı verdiği tepkinin kısa dönemde uzun dönem denge değerinin üstünde kalabildiğini belirtmiştir. Literatürde "Hedefi Aşma" (overshooting) olarak da adlandırılan bu durum, ülke içindeki fiyat düzeyindeki denge değerinin finansal piyasalar kadar hızlı değişmemesinden kaynaklanmaktadır. Bu çalışmadaki amaç Türkiye'deki parasal şokların, kısa dönemde oluşan döviz kuru dengesinin uzun dönem denge hedefini aşıp aşmadiğııı test etmektir. Bu amaca yönelik olarak $A R D L(5,6,1,10$, 5) Hata Düzeltme Modeli (ECM) kullanılmış ve 2000: 01 ve 2014: 08 tarih aralı̆̆ sonuçlar istatistiksel olarak anlamlı olmasa da kısa dönem döviz kuru denge değerinin "hedefi aşma teoremi" ile uyumlu şekilde uzun dönem denge değerinin üstüne çıktı̆̆ını göstermiştir.

Anahtar kelimeler: Döviz kurları, Yapışkan fiyat modeli parasal yaklaşım, ARDL.

JEL kodlarn: F31, C32 


\section{INTRODUCTION}

Since the introduction of the flexible exchange rate system in the 1970s, the factors that determine the equilibrium exchange rate have been subject to a tremendous amount of both theoretical and empirical studies. Although leading exchange rate theories, such as purchasing power parity, interest parity, balance of payments, monetary and the portfolio approach, attempt to explain the equilibrium exchange rate through existing data by employing different econometric techniques, most of them are unable to make correct forecasts. Predicting exchange rate movements is a difficult task, because economic forces affect exchange rates through different channels. One of the most important theories that explain the reason for exchange rate volatility is the Sticky Price Monetary Model. Initially introduced in 1976 by Dornbusch, the exchange rate is said to overshoot when its short-term response to changes in money supply is greater than its long-term response, as the domestic price level does not move instantaneously.

Purchasing Power Parity (PPP) provides an explanation of the exchange rate in financial markets through relative changes in real prices formed in goods markets. Interest parity (covered or uncovered), however, examines the relationship between interest differentials and the exchange rate rather than the effect of the equilibrium in goods markets on foreign exchange rates, as in purchasing power parity (PPP). The most fundamental assumption in the interest parity condition is that the countries being analyzed must have the same level of risk. Namely, if there is a difference in interest returns for an investment instrument with the same maturity and level of risk between two countries, this will lead to interest arbitrage opportunities in an environment where the free movement of capital prevails. Hence, international investors buy or sell forward discount or premium exchange rates in order to sweep out arbitrage opportunities in interest rates. Thereby, the market reaches a new equilibrium rate of exchange. The Interest Parity Theorem suggests that among investment instruments with the same level of risk denominated in different currencies, the currency of the country for which interest rate is higher shall depreciate, or the currency of the other country shall appreciate. In calculating the return of the investment made in foreign currency for the following period; spot rate $(\mathrm{E})$ and forward rate $(\mathrm{F})$ of the following period or expected exchange rate $\left(\mathrm{E}_{\mathrm{c}}\right)$ are taken into consideration, and the return is calculated as $\mathrm{F}\left(\right.$ or $\left.\mathrm{E}_{\mathrm{c}}\right) / \mathrm{E}\left(1+\mathrm{i}^{*}\right)$. If $\mathrm{F}\left(\right.$ or $\left.\mathrm{E}_{\mathrm{c}}\right) / \mathrm{E}\left(1+\mathrm{i}^{*}\right)>(1+\mathrm{i})$, it is anticipated that the investment will be made on foreign currency, whereas if $\mathrm{F}$ (or $\left.\mathrm{E}_{\mathrm{c}}\right) / \mathrm{E}\left(1+\mathrm{i}^{*}\right)<(1+\mathrm{i})$, the investment will be made on domestic currency. Low arbitrage costs in financial markets equalize domestic interest returns with an effective rate of return on foreign currency. The effective rate of return is calculated as the foreign interest return plus forward premium or discount. Unless rates of return are equalized, there will be arbitrage opportunities, which will immediately be swept out by markets. If the yields in financial markets equalize, with respect to expected exchange rate, this is called uncovered interest parity, whereas if the yields equalize in the forward exchange rate markets, it is called covered interest parity. Uncovered interest parity relations for countries A and B can be written as:

$i_{d}=i_{f}+\left(E_{e}-E\right) / E$

One of the most important theories, which explain the reason of exchange rate volatility in the short-run, is the Sticky Price Monetary Model. The theory is based on the uncovered interest 
parity equation and the money demand function. The model assumes that the uncovered interest parity holds constantly and purchasing power parity holds in the long run. Provided that prices are fully flexible in the long run, a shock in money market would cause a change in domestic price in the long run, to restore the equilibrium in the money market. To some extent, the Sticky Price Model explains exchange rate volatility and why exchange rates deviate from the PPP theorem in the short run. In this model, the main emphasis is given to financial market arbitrage rather than goods market arbitrage. Overshooting of exchange rates exists in financial markets because purchasing power parity does not hold in the short run, and the spot rate is more volatile than the forward rate. If there is no change in money demand, and country A increases its money supply, then the interest rate will fall. However, purchasing power parity holds in the long run. In other words, if the price level is expected to rise in country A and so does the exchange rate. The higher the expected future rate is, the higher the forward rate is now. However, the forward premium of currency should fall to maintain interest parity. Therefore, the spot exchange rate $(E)$ increases more than the forward rate $(F)$ in the short run but over time, the price level and interest rate in country A will increase, and the exchange rate will begin to fall towards its long run equilibrium rate.

Dornbusch (1976) asserted that while an increase in interest rates should cause the nominal exchange rate to appreciate instantaneously, it should subsequently depreciate, consistent with uncovered interest parity. It is stated that the depreciation (appreciation) in the exchange rate in the short run is larger than the depreciation (appreciation) in the long run. As a consequence, this initial excess depreciation (appreciation) creates room for the long run equilibrium through appreciation (depreciation). Furthermore, according to the uncovered interest parity theorem, the decline in the interest rate causes capital outflows and depreciation in the short run, whereas decline in the interest rate in the long run causes an expected appreciation. As the exchange rate overshoots its long run value in the short run, the domestic currency might be expected to appreciate to compensate for the lower rate of interest on domestic bonds.

This paper proceeds as follows: Section II summarizes recent empirical studies. Section III describes variables and discusses the empirical findings of the model. Section IV provides concluding remarks.

\section{LITERATURE REVIEW}

Empirical studies show contradictory results. According to various studies, following a contractionary monetary shock, the real exchange rate either depreciates or it appreciates for a long period of up to three years. In the literature this paradoxical result is characterized as an exchange rate puzzle and delayed overshooting. Few empirical studies have been found to support results for the overshooting hypothesis (Sims (1992), Kim \& Roubini (2000), Mojon \& Peersman (2003)). Eichenbaum \& Evans (1995) examined the period between 1974 and 1990 and found that expansionary U.S. monetary shock had initially led to an appreciation of the U.S. dollar, but which subsequently depreciated over two to three years. Scholl \& Uhlig (2008) showed the existence of delayed overshooting for USA vis-à-vis the exchange rates of Germany, UK, Japan and G7 countries for the period between 1975 and 2002. Kim (2005) argued that the intervention of the central bank on foreign exchange markets is the main reason for delayed overshooting for the Canadian-US bilateral exchange rates. 
Various empirical studies have concluded that the exchange rate overshoots its long run value within one to three years, which is called delayed overshooting. Heinlein \& Krolzig (2012) studied the determinants of US Dollar and UK Pound Sterling exchange rates through the output gap, interest rate and inflation differentials. They found strong evidence for delayed overshooting. Although the sticky price model is in accordance with the uncovered interest parity conditions, delayed overshooting contradicts this assumption. According to Gourinchas \& Tornell (2004), the overshooting puzzle arises as investors overestimate transitory interest rate shocks. Kim (2005) used Canadian data to examine bilateral exchange rates between Canada and the U.S. According to this study, the delayed overshooting effect of monetary policy shocks is due to foreign exchange interventions 'leaning against the wind'.

Bjornland (2009) studied Australian, Canadian, New Zealand, and Swedish exchange rates. Consistent with the Dornbusch overshooting hypothesis, the results revealed that contractionary monetary policy leads to the immediate appreciation of real exchange rates in a few quarters, which gradually depreciates. Taylor (1995) states that certain empirical studies found unexpected signs. These controversial signs can be explained by other factors, such as the wealth effect.

Since the overshooting hypothesis relies on the validity of the interest parity theorem, the study has provided various examples of empirical research concerning this issue. Chinn \& Meredith (2005), in turn, could not initially support interest parity relationship in the short run, but achieved positive outcomes for the period 1980-2000 in the study they conducted with five-year interest rates. For the period 1948-1988, Metin (1993) could not reach empirical outcomes that supported uncovered interest parity. However, most of the studies were carried out with one-year interest rates. Saatçioğlu et. al. (2007) reached empirical findings indicating that in the long run uncovered parity conditions were satisfied for Turkey. Positive variations in local interest rates have brought almost direct increases in the expected return on foreign exchange rates. The empirical research does not produce unique result for the issue whether interest parity theorem holds or not.

Nieh \& Wang (2005) analyzed Taiwan currency TWD/USD exchange rates by employing both Johansen cointegration and ARDL bound test for the period between 1986 and 2003 and found that ARDL model supports overshooting. Haghighat \& Shojaei (2014) investigated overshooting hypothesis for Iran by employing ARDL test for the period from 2002 to 2011. This study states that empirical findings for Iran supporting the theory. Amongst the empirical research conducted using Turkish data, one study has been found relating to the overshooting hypothesis. Bahmani-Oskooee \& Kara (2000) examined whether the Turkish Lira has overshot its short run value by employing ARDL cointegration and error-correction modeling. The results of the study revealed that the exchange rate has overshot in response to the rapid increase in Turkish relative money supply.

\section{THE MODEL}

The model is composed of a combination of Purchasing Power Parity (PPP) theorem and the Quantity Theory of Money. First of all, let us define the variable $S$ as the ratio of general level of prices in Turkey $\left(P_{T}\right)$ to general level of prices in the U.S. (Pus) as shown in equation (1). 


$$
S=\frac{P_{T}}{P_{U S}}
$$

With reference to the Quantity Theory of Money, the equations $M_{T} \cdot V_{T}=P_{T} \cdot Y_{T}$ and $M_{U S} \cdot V_{U S}=P_{U S} . Y_{U S}$ can be defined for Turkey and the U.S. respectively. Arranging the terms $P_{T}$ and Pus for equation (1) gives;

$$
S=\left(\frac{M_{T}}{M_{U S}}\right)\left(\frac{V_{T}}{V_{U S}}\right)\left(\frac{Y_{U S}}{Y_{T}}\right)
$$

Equation (2) shows the exchange rate calculated in terms of relative money supply, relative velocity of money and relative income. Taking the logarithms of both sides in equation (2), we obtain equation (3).

$$
\log S=\left(\log M_{T}-\log M_{U S}\right)-\left(\log Y_{T}-\log Y_{U S}\right)+\left(\log V_{T}-\log V_{U S}\right)
$$

The main sources of the velocity of money for both countries are the interest rate and the rate of inflation (Bahmani-Oskooe \& Kara, 2000). In the model built, interest rate of Turkey and the U.S. are denoted by $i_{T}$ and $i_{U S}$, and rates of inflation are denoted by $\pi_{T}$ and $\pi_{U S}$ respectively.

$$
\log S=\left(\log M_{T}-\log M_{U S}\right)-\left(\log Y_{T}-\log Y_{U S}\right)+\left(i_{T}-i_{U S}\right)+\left(\pi_{T}-\pi_{U S}\right)
$$

The monetary model that results in turn is;

$$
s_{t}=\alpha+\beta_{1} m_{t}+\beta_{2} y_{t}+\beta_{3} i_{t}+\beta_{4} \pi_{t}+\varepsilon_{t}
$$

Here, $s=\log S, \quad m=\left(\log M_{T}-\log M_{U S}\right), y=\left(\log Y_{T}-\log Y_{U S}\right), i=\left(i_{T}-i_{U S}\right), \pi=\left(\pi_{T}-\pi_{U S}\right)$ and $\varepsilon$ denote the error term. As we form the expectations, it is expected that when the growth of money supply in Turkey is greater than the U.S., TL would depreciate. Monetarists also suggest $\beta_{1}=1$. According to the monetarist view, when income growth in Turkey is relatively larger than the U.S., the $\beta_{2}$ coefficient is expected to be negative, as it will lead to an appreciation in the nominal exchange rate of TL. $\beta_{3}$ and $\beta_{4}$ coefficients, in turn, are both expected to have positive signs since the comparatively higher rates of interest and inflation in Turkey respectively will lead a depreciation in TL. Dornbusch's (1976) sticky price model estimated $\beta_{3}=0$.

\section{DATA, ANALYSIS, AND FINDINGS}

$S, M_{T}$ and $Y_{T}$ series employed in estimating the model are derived from the Central Bank of the Republic of Turkey; $M_{U S}$ and $i_{U S}$ are taken from the Federal Reserve Bank of St. Louis; $Y_{U S}$ ,$\pi_{T}$ and $\pi_{U S}$ are taken from International Financial Statistics of IMF; and $i_{T}$ is taken from Borsa Istanbul (The Istanbul Stock Exchange). All series are on a monthly basis and belong to the period from January 2000 to August 2014.

Since the overshooting hypothesis is a short-term phenomenon, and error correction model is estimated with cointegration analysis in order to test the hypothesis. At the first stage of the analysis, unit root tests were applied and the results are reported in Table 1. 
Table 1. Unit Root Tests

\begin{tabular}{|c|c|c|c|c|}
\hline \multirow{2}{*}{ Variables } & \multicolumn{2}{|c|}{ ADF } & \multicolumn{2}{|c|}{ PP } \\
\hline & Level & Trend & Level & Trend \\
\hline $\mathrm{s}$ & $-3.146(2)^{* *}$ & $-3.371(1)$ & $-3.185^{* *}$ & -3.185 \\
\hline $\mathrm{m}$ & $-3.076(0)^{* *}$ & $-1.676(0)$ & $-3.161 * *$ & -1.651 \\
\hline $\mathrm{y}$ & $-2.426(12)$ & $-2.422(12)$ & $-5.108 * * *$ & $-5.087 * * *$ \\
\hline $\mathrm{i}$ & $-34.979(13) * * *$ & $-27.206(13) * * *$ & $-11.203 * * *$ & $-12.290 * * *$ \\
\hline $\inf$ & $-2.071(0)$ & $-2.026(0)$ & -2.192 & -2.371 \\
\hline$\Delta \mathrm{s}$ & $-8.647(0) * * *$ & $-8.697(0) * * *$ & $-8.579 * * *$ & $-8.544 * * *$ \\
\hline$\Delta \mathrm{m}$ & $-14.806(0) * * *$ & $-15.376(0)^{* * *}$ & $-14.725 * * *$ & $-15.238 * * *$ \\
\hline$\Delta \mathrm{y}$ & $-3.570(11)^{* * *}$ & $-3.575(11)^{* *}$ & $-27.296 * * *$ & $-27.086 * * *$ \\
\hline$\Delta \mathrm{i}$ & $-13.028(13)^{* * *}$ & $-8.530(3) * * *$ & $-78.201 * * *$ & $-77.751 * * *$ \\
\hline$\Delta \inf$ & $-12.043(0)^{* * *}$ & $-12.065(0)^{* * *}$ & $-12.102 * * *$ & $-12.098 * * *$ \\
\hline
\end{tabular}

The optimal lags for ADF test were selected by Schwarz information criterion.

The bandwidth for PP test was selected with Newey-West using Bartlett kernel.

$\left(^{* * *}\right),\left(^{* *}\right)$ and $\left(^{*}\right)$ indicate that the corresponding coefficient is significant at $1 \%, 5 \%$, and $10 \%$ levels, respectively

Analysis of unit root tests reveals that variables are integrated at various degrees. In order to analyze series integrated at various degrees, the ARDL (Autoregressive Distributed Lag) method developed by Pesaran et al. (2001) is used. From equation (5), the ARDL error correction model is,

$$
\begin{aligned}
\Delta s_{t} & =d_{0}+d_{1} s_{t-1}+d_{2} m_{t-1}+d_{3} y_{t-1}+d_{4} i_{t-1}+d_{5} \pi_{t-1}+\sum_{j=0}^{p} a_{j} \Delta s_{t-j} \\
& +\sum_{j=0}^{q_{1}} b_{j} \Delta m_{t-j}+\sum_{j=0}^{q_{2}} c_{j} \Delta y_{t-j}+\sum_{j=0}^{q_{3}} e_{j} \Delta i_{t-j}+\sum_{j=0}^{q_{4}} f_{j} \Delta \pi_{t-j}+\varepsilon_{t}
\end{aligned}
$$

While the null hypothesis $H_{0}: d_{1}=d_{2}=d_{3}=d_{4}=d_{5}=0$ in this method implies that there is no cointegration, the alternative hypothesis $H_{1}: d_{j} \neq 0 \quad \exists j i c ̧ i n(j=1,2,3,4,5)$ indicates the existence of cointegration. For statistical computation F-test is employed and the critical values of boundaries $I(0), I(1)$ are taken from Pesaran et al. (2001). If the calculated statistic is below the value of the lower boundary $I(0)$, it is inferred that there is no cointegration, and if it is between lower and upper boundaries, i.e. $I(0)$ and $I(1)$ values, it is within the zone of indifference, and finally, if it is above the upper boundary $I(1)$, then it indicates that there is a cointegration.

The study reveals that there is a cointegration since the F-statistic is larger than the upper boundary as reported in Table 2 . 
Table 2. Test Results

\begin{tabular}{ccc} 
& Constant & Trend \\
\hline \hline F_stat & 5.09 & 5.36 \\
$I(0)$ & 2.86 & 3.47 \\
$I(1)$ & 4.01 & 4.57 \\
\hline \hline
\end{tabular}

Table 3. Full information estimate of ARDL model using SIC criterion

\begin{tabular}{|c|c|c|c|c|c|c|c|c|c|c|c|}
\hline \multirow{2}{*}{ Variables } & \multicolumn{11}{|l|}{ Lag order } \\
\hline & 0 & 1 & 2 & 3 & 4 & 5 & 6 & 7 & 8 & 9 & 10 \\
\hline$\Delta \mathrm{s}$ & & $\begin{array}{l}0.3831 \\
(4.524)\end{array}$ & $\begin{array}{l}-0.3200 \\
(-3.650)\end{array}$ & $\begin{array}{l}0.0659 \\
(0.736)\end{array}$ & $\begin{array}{l}-0.1307 \\
(-1.534)\end{array}$ & $\begin{array}{l}-0.2051 \\
(-2.495)\end{array}$ & & & & & \\
\hline$\Delta \mathrm{m}$ & $\begin{array}{c}0.006180 \\
(0.373)\end{array}$ & $\begin{array}{l}0.0188 \\
(1.159)\end{array}$ & $\begin{array}{l}-0.0298 \\
(-1.831)\end{array}$ & $\begin{array}{l}-0.0311 \\
(-1.827)\end{array}$ & $\begin{array}{l}-0.0281 \\
(-1.701)\end{array}$ & $\begin{array}{l}0.0294 \\
(1.896)\end{array}$ & $\begin{array}{l}0.0383 \\
(2.491)\end{array}$ & & & & \\
\hline$\Delta \mathrm{y}$ & $\begin{array}{c}0.024469 \\
(2.041)\end{array}$ & & & & & & & & & & \\
\hline$\Delta \mathrm{i}$ & $\begin{array}{l}0.0001 \\
(3.369)\end{array}$ & $\begin{array}{l}-0.0002 \\
(-2.785)\end{array}$ & $\begin{array}{l}-0.0002 \\
(-2.216)\end{array}$ & $\begin{array}{l}-0.0003 \\
(-3.522)\end{array}$ & $\begin{array}{l}-0.0001 \\
(-2.304)\end{array}$ & $\begin{array}{l}-0.0001 \\
(-2.156)\end{array}$ & $\begin{array}{l}-0.0001 \\
(-0.929)\end{array}$ & $\begin{array}{l}-0.0001 \\
(0.547)\end{array}$ & $\begin{array}{l}-0.0001 \\
(1.955)\end{array}$ & $\begin{array}{l}-0.0001 \\
(1.030)\end{array}$ & $\begin{array}{l}-0.0001 \\
(1.748)\end{array}$ \\
\hline$\Delta \mathrm{inf}$ & $\begin{array}{l}0.0006 \\
(1.655)\end{array}$ & $\begin{array}{l}-0.0003 \\
(-0.830)\end{array}$ & $\begin{array}{l}0.0002 \\
(0.602)\end{array}$ & $\begin{array}{l}-0.0005 \\
(-1.505)\end{array}$ & $\begin{array}{l}-0.0010 \\
(-2.782)\end{array}$ & $\begin{array}{l}0.0008 \\
(2.067)\end{array}$ & & & & & \\
\hline $\mathrm{C}$ & $\begin{array}{c}-0.00001 \\
(0.059)\end{array}$ & & & & & & & & & & \\
\hline $\mathrm{EC}$ & & $\begin{array}{c}0.024870 \\
(5.287)\end{array}$ & & & & & & & & & \\
\hline
\end{tabular}

*Number inside the parentheses beneath each coefficient is the absolute value of t-ratio.

The adjusted $\mathrm{R}^{2}=0.5848$ and $\mathrm{DW}=1.9000$

By concentrating on the signs of lagged coefficient estimates of $\Delta \mathrm{m}$ variable, it appears that the Lira depreciates in the first and the following month (as indicated by the first two positive coefficients), and then it starts to appreciate (as indicated by the negative coefficient for the following three months) supporting the overshooting hypothesis in the short run, even though many of these coefficients are insignificant. The results of the study show that a relatively higher income growth in Turkey depreciates the Lira. This can be explained by the dependency of Turkish manufacturing industry on imported intermediate goods. Even though the coefficient of inflation varies, it is not statistically significant. The statistically most robust and consistent coefficient in the model belongs to the interest rate variable. An increase in interest rates initially leads Lira to depreciate, and then to appreciate in the subsequent months. Based on this conclusion, it can be concluded that economic agents, conducting transactions in foreign exchange in financial markets, respond to the interest rate variable rather than monetary variable in the short-run.

$$
s=1.45-0.21 m+0.04 y-0.02 i+0.02 \pi
$$

As it is seen from the long run equation (7), an increase in money supply cause a slight appreciation of Turkish Lira. This situation can be interpreted as a sign of overshooting because although the first two coefficients of money supply are positive in the short run (indicating depreciation of Turkish Lira), it is seen that long run coefficient is negative 
(indicating appreciation of Turkish Lira). When both and short equations are analyzed, most consistent and also statistically significant relationship has been seen between exchange rate and interest rate. One percent increase in interest rate cause an appreciation of Turkish lira both in the short run and long run.

\section{CONCLUSION}

The results of this study support the overshooting hypothesis for TL/ $\$$ exchange rate for the period between 2000 and 2014. The result of this study supports overshooting hypothesis. However, since the prices of variables in financial markets could change much more rapidly compared with the real economy, many empirical studies could not achieve conclusions consistent with the theory in the short run, as exogenous effects are intense. Accordingly, predicting exchange rate movements is a complex task, since a variety of economic forces affect exchange rates through different channels, such as the differential speed of adjustment in different markets, speculative attacks, the role of the media, etc. Not only long run structural and cyclical forces, but also short run speculative forces have substantial effects on the determination of both the level and the volatility of exchange rates. Therefore, the results achieved in empirical research do not reveal consistency. It seems that the factors that play a role in the determination of exchange rates will continue to be the subject of a large amount of both empirical and theoretical research.

\section{REFERENCES}

Bahmani-Oskooee, M. \& Kara, O. (2000). Exchange rate overshooting in Turkey. Economics Letters, 68, 89-93.

Bjornland, H. (2009). Monetary Policy and Exchange Rate Overshooting: Dornbusch was right after all. Journal of International Economics, 79, 64-77.

Chinn, M.D. \& Meredith, G. (2005). Testing Uncovered Interest Parity at Short and Long Horizons during the Post-Bretton Woods Era. NBER Working Paper, 1107.

Dornbusch, R. (1976). Expectations and Exchange Rates Dynamics. Journal of Political Economy, 84, 1161-1176.

Eichenbaum, M. \& Evans, C, L. (1995). Some Empirical Evidence on the Effects of Monetary Policy Shocks on Exchange Rates. Quarterly Journal of Economics, 110, 975-1010.

Gourinchas, P.-O. \& Tornell, A. (2004). Exchange Rate Puzzles and Distorted Beliefs. Journal of International Economics, 64, $303-333$.

Haghighat, A. \& Shojaei, T. (2014). Exchange Rate Overshooting in Iran. Academic Journal of Research in Economics \& Management, 2(3), 38-43.

Heinlein, R. \& Krolzig, H. (2012). Effects of Monetary Policy on the US Dollar/UK Pound Exchange Rate. Is there a "Delayed Overshooting Puzzle?". Review of International Economics, 20(3), 443-467.

Kim, S. \& Roubini, N. (2000). Exchange Rate Anomalies in the Industrial Countries: A Solution with a Structural VAR Approach. Journal of Monetary Economics, 45, 561-586. 
Kim, S. (2005). Monetary policy, foreign exchange policy, and delayed overshooting. Journal of Money, Credit and Banking, 37, 775-782.

Mojon, B. \& Peersman, G. (2003). A VAR Description of The Effects of Monetary Policy in the Individual Countries of the Euro Area. European Central Bank Working Paper Series, 92, $56-74$.

Metin, K. (1993). Türk Ekonomisinin Uzun Dönem Enflasyon Analiz: Bir Ampirik Yaklaşım. Ekonomik Yaklaşım, 4(8), 97-115.

Nieh, C. \& Wang, Y. (2005). ARDL Approach to the Exchange Rate Overshooting in Taiwan. Review of Quantative Finance and Accounting, 25, 55-71

Pesaran, M. H., Shin Y. \& Smith, R. J. (2001). Bounds Testing Approaches to the Analysis of Long-Run Relationship. Journal of Applied Econometrics, 16, 289-326.

Saatçioğlu, C., Korap, H. L. \& Volkan, A. G. (2007). Modeling Purchasing Power Parity Using Co-Integration: Evidence from Turkey. Journal of American Academy and Business, 11, $51-57$.

Sims, C.A. (1992). Interpreting the Macroeconomic Time Series Facts: The Effects of Monetary Policy. European Economic Review, 36, 975-1011.

Scholl, A. \& Uhlig, H. (2008). New Evidence on The Puzzles: Results from Agnostic Identification on Monetary Policy and Exchange Rates. Journal of International Economics, 76, 1-13.

Taylor, M. (1995). The Economics of Exchange Rates. Journal of Economic Literature, 33(1), 1347.

\section{Appendix. Data Definition}

$S=$ Nominal exchange rate defined as number of Turkish lira per U.S. dollar,

$M_{T}=\mathrm{M} 1$ monetary aggregate for the Turkey,

$M_{U S}=\mathrm{M} 1$ monetary aggregate for the U.S.,

$Y_{T} \quad=$ Index of industrial production for the Turkey,

$Y_{U S}=$ Index of industrial production for the U.S.,

$i_{T} \quad=$ Interest rate for the Turkey,

$i_{U S}=$ Interest rate for the U.S.,

$\pi_{T}=$ CPI based rate of inflation for the Turkey,

$\pi_{U S}=$ CPI based rate of inflation for the U.S. 